\section{From Colonial Economics to Development Studies}

The Institute of Development Studies was set up as a centre for teaching and research on the problems of development, and has drawn together a number of experienced professionals in economics (especially agricultural economics), manpower planning. political science, public administration and sociology.

"Development" is, of course, by no means an entirely new field of study. As metropolitan powers becane more involved in the affairs of their colonies during the first half of this century, it began to be realised that these problems were to some extent specialised. "Anthropology", which from the beginning implicitiy treated the object of study as the indigenous man of the colonial world, received a good deal of support from colonial governments, because of its usefulness to administrators, as did "Tropical agriculture". "Colonial economics" also appeared in University syliabusesp this: was farticularly designed for those going to work overseas, and was mostly descriptive.

A new phase opened in the 1950's. Changes in fields of academic studies reflected changes in the real world, though - as is usually the case- with some delay. Since most of the governments of the poorer countries, especially those which became independent after the Second World War, gave a very high priority to development, which was thought of an almost exclusively economic process, "development economics" began to emerge as a seperate subject, much more widely taught. Although this was a big advance on "colonial economics", because of considerably greater emphasis on the conditions for progress, it was still part of the syllabus of economics, and not a

\section{Dudley Seers}

very reputable part in the eyes of the profession, who continue to be mainly concerned with the local problems of the small group of countries bordering the North Atlantic.

The 1960's could well be called the decade of disillusion. The development plans prepared in many countries, often with the help of highly sophistieated economists, have proved of limited use as guides to policy decisions. They were very largely government investment programmes. Most of lis working for governments have come, however, even if slowly and perhaps reluctantly, to realise that what holds up development is usually not only, or even primarily, lack of capital, but systems of education or land tenure, politicians unwilling or unable to change the social structure, administrative systems which are archaic or nepotic, etc., etc.

Economists writing or teaching about development problems began, as a consequence, to say that "social factors" ought also to be taken into account. In fact, however, most of them, after giving a nod in this direction, still restricted their analysis, and more dangerously their recommendations, very much to a range of econqmic variables, especially those which were quantifiable.

No doubt the majority of economis te wpuld have preferred to hold the line there. After all. interesting possibilities were still open to those researching on the economic patterns of development. But in some fields of worie such restraint became more and more obviously inappropriate, as the conditions for progress were more deeply explored. The difficulty of mobilising the agricultural sector, which has become increasingly 
important in the theory and practice of development, is clearly more than just a question of price policy, or even of arranging for irrigation and the distribution of fertilisers.

It was problems in the field of manpower that finally made a new approach inevitable. Those concerned in actual work, especially in tropical Africa, could hardly help seeing that development over the next two or three decades depended very much on the supply of professionally and technically qualified people. The first steps in this new field were mostly quantitative, and indeed bore a strong formal resemblance to the existing body of economists. The requirements of "human capital" were in relation to the expected levels of national income, like estimates of needs for physical capital, and these manpower projections were in turn converted into. required levels of output of the educational system, which was treated as a sort of capitalgoods industry.

But while conventional capital theory can be defined within this formal framework, this is impossible for the economics of manpower. Estimates of the number of graduates required lead inevitably into a discussion of the nature of the education provided - the structure of universities by departments, for example, and the content of the syllabuses taugit. Similarly, manpower planning poses major and broad issues of income and migration policy Whereas in the case of the markets for merchandise one can make useful iropositions about their economic operation (in terms of elasticities for example), "purely economic" propositions about the market for manpower do not take one very far and may be highly misleading.
This foints to a fundamental ireason why"economic factors" cannot usefully be studied in isolation for economically backward countries. While the political and social framework is broadly treated as given by economists in industrial countries even for quite wide movements in economic variables, and this is not obviously unreasonable, such treatment just does not work in other countries. Indeed, for them, one could almost turn this apfroach on its head, the problem being not so much to achieve economic advance given certan political and social constraints, as to achieve social and political change within an economic framework, which sets the room for manceuvre". Custodians of received doctrine used to question whether "development economics" constituted a recognisable separate branch of economics. How one must ask: can tine economics of development be usefylly studied in isolation from $i$ ts politics and sociology?

Whilst economists were making inroads into these unmapped territories, sociologists and political scientists were starting - somewhat belatedly, especially in Britain - to achieve new insights into other aspects of the process of development; and economists were - perhaps even more belatedlybecoming aware of this. The political scientists found that they needed a methodological revolution (in this case largely under the influence of studies on South Asia), this is still in prpgress, but it is already producing a new conceptual structure, which fits to some extent that of economics. So an extension of the area patrolled by economists has been meeting sorties in the opposite direction from other disciplines and we are beginning to study the process of development as a whole.

* I owe this formulation to a contribution by Thomas Vietorisz at the recent conference of the Society for International Development in Washington. 
The Institute of Development Studies is constructed and operates in ways which reflect a recognition of need to look on development in this way, indeed that the interesting area is precisely where economic and non-economic forces interact. Hence the broad range of subjects covered by its staff. Moreover, when recruiting for senior posts, the Institute has given weight to experience in helping overseas governt ments, rather than to teaching in Britain; practical work comfels people to take account of factors outside their own speciality.

The difficulty is, of course, to achieve a genuine fusion of disciplines. Past attempts to set up "inter-disciplinary" syllabuses have usually expected the student to integrate for himself a number of different disciplines (as is broadly still true, for example, of the Oxford rubric for Philosophy, Polftics. and Economics). The Institute is at least alert to this danger (as we are to the other risk - that "interdisciplinary" work will be heavily descriptive rather than analytic, and therefcre of little use as a basis for further studies). Those in charge of research or running seminars draw on the experience of collegues in other disciplines. Future projects will be carried out by teans, covering several fields, rather than by individuals. Various Fellows are already cooperating in an introduction to development, and texts for our seminars and courses will also be produced co-operatively.

There is one otiler difference which should be mentioned. "Colonial economics" was concerned largely with internal problems, except for fluctuating connodity markets which were taken as facts of life, almost completely beyond tile control of any particular colony. The political pressures from the Third World have compelled those working on development problems to do so in the context of the whole relationship between rich countries and poor, including aid and trade, and the adequacy of international machinery for correcting the growing inequality between them.

We in the Institute hope to build up development studies which will be help to the countries of Africa, Asia, Latin America and the Caribbean. But not merely to them. Other nations of ten show recognisable symptorns of strain in the development process - for example, chronic difficulties in foreign payments, shortages of engineers or racial frictions. Many comparatively well-to-do countries face familiar structural obstacles to development such as somewhat antiquated educational or administrative systems - 3ritain is a case in foint! The trade of every country, especially Britain, suffers from the lurching and uncertain progress of the world economy, and the fallure of large parts of it to show any 8 ignificant progress at al1. The development of development studies will, therefore, throw an increasing amount of light on our problems too. 